Research Article

\title{
The Key Construction Technology Research on the Intercontinental Shanghai Wonderland
}

\author{
Peng Jiang, ${ }^{1}$ Shaole Yu $\mathbb{D}^{2},{ }^{2}$ Wei Luan, ${ }^{2}$ Xinxi Chen, ${ }^{2}$ Yang Qin, ${ }^{3}$ and Zhongfu Li ${ }^{1}$ \\ ${ }^{1}$ Department of Construction Management, Dalian University of Technology, Dalian 116024, China \\ ${ }^{2}$ China Construction Eighth Engineering Division Co., Ltd., Shanghai 200135, China \\ ${ }^{3}$ East China Architectural Design \& Research Institute Co., Ltd., Shanghai 200011, China \\ Correspondence should be addressed to Shaole Yu; yushaole10@163.com
}

Received 16 May 2020; Revised 2 September 2020; Accepted 23 September 2020; Published 22 October 2020

Academic Editor: Jia-wen Zhou

Copyright (C) 2020 Peng Jiang et al. This is an open access article distributed under the Creative Commons Attribution License, which permits unrestricted use, distribution, and reproduction in any medium, provided the original work is properly cited.

The Intercontinental Shanghai Wonderland is the first natural ecological hotel built in an abandoned mine in the world, which faces many difficulties in the construction process. To solve the difficult problems in the construction process, the study was carried out from the stability analysis of the deep pit cliff, the mechanical performance of the structure, and the construction technology. The Intercontinental Shanghai Wonderland is built around the abandoned deep pit cliffs, and the stability of the deep pit cliffs directly affects the safety of the building. The dynamic response characteristics and the instability characteristics of the mine slope under the dynamic response were analyzed by a three-dimensional dynamic finite element method. The calculation results showed that with effective anchoring support measures, the stability coefficient of slope under static load and small earthquakes was large, which had a certain safety margin. Under the action of large earthquakes, the slope could still meet the stability requirements. The structure of the Intercontinental Shanghai Wonderland is a unique two-point support structure system. It shows the deformation and stress characteristics of one fixed end and one simply supported end under horizontal load. The elastic-plastic time history response of structures under actions of rare earthquakes was analyzed through the finite element analysis software. The analysis results show that the current structural system along with the design of component size and strength can meet the seismic performance of the structure under actions of rare earthquakes. The Intercontinental Shanghai Wonderland was built in a stone pit $88 \mathrm{~m}$ below the surface. Therefore, the transportation of materials was a difficulty in the construction process. A set of ultradeep concrete downward conveying equipment was invented to solve the difficulty. The construction process of the whole structure was simulated by finite element software, which provided a safety guarantee for the construction of the whole structure.

\section{Introduction}

The Intercontinental Shanghai Wonderland is the first natural ecological hotel built in an abandoned mine with $-88 \mathrm{~m}$ depth, which has set a world record for the lowest five-star hotel in the world. The Intercontinental Shanghai Wonderland and the Burj al Arab are listed as two of the world's top 10 architectural wonders. The Intercontinental Shanghai Wonderland is close to the mine cliff, which has a height of more than $80 \mathrm{~m}$. The stability of the cliff slope has a significant influence on the structure safety. According to the mine pit construction environment, a new type of twopoint support structure is adopted in the Intercontinental
Shanghai Wonderland. The mechanical characteristics of the structure under horizontal load are not typical "cantilever beam" characteristics in high-rise buildings. It shows a special "simply supported beam" characteristic with one end fixed and the other end hinged. The concrete transportation had to be carried down the cliff for $80 \mathrm{~m}$, and the amount of concrete foundation at the bottom of the pit exceeds $50,000 \mathrm{~m}^{3}$. There are many challenges during the construction process.

For complex structural engineering, it is essential to master the mechanical properties in the process of structure construction. However, the mechanical properties in the construction process and the final state of completion are 
quite different. Therefore, the mechanical analysis of the construction process is required for complex structures. At the end of the 19th century, Meshchersky [1] first proposed time-varying rigid body mechanics. Southwell [2] studied the time-varying mechanism of a thick-walled cylinder that wraps a wire around an elastic shaft. From the late 1980s to the 1990s, scholars in many countries have carried out studies on basic concepts and basic theories of time-varying mechanical systems. Naumov [3] summarized these findings in his research. In China, Cao [4] conducted systematic research on some basic theories of time-varying mechanics and gradually formed the framework of a time-varying mechanical system. A reasonable construction scheme established by analyzing the mechanical performance of structures can solve many problems in the construction process of complex structures. Li et al. [5] introduced the construction process of the Beijing Olympic Water Cube Water Project. The main stadium of the Beijing Olympic Water Cube Water Project, with a lifting weight of $6300 \mathrm{t}$ and lifting height of $30 \mathrm{~m}$, was constructed by bulk-way assembly technology at high altitude. Fan et al. [6] studied the construction technology of the Shanghai World Financial Center, which is one of the highest buildings in the world. A refined finite element model was developed to conduct a fullprocess analysis of the construction of the Shanghai World Financial Center. In this project, the discrete analysis method of time-varying structures and the age-adjusted effective modulus method were used. Tian et al. [7] investigated the construction process of the roof of the main stadium for the World University Game, which was a singlelayer folded-plane latticed shell structure system. The internal force and deformation of the World University Games' main stadium during the construction process were analyzed by using the method of constructional mechanics, and thus the optimal constructional plan was obtained. Lu et al. [8] introduced the construction process of the T3 terminal building of Chongqing Jiangbei International Airport. The high-altitude slip method was adopted in the steel structure engineering of the main building of the T3 terminal building, which was a space curved surface with a lifting height of $49 \mathrm{~m}$ and a lifting weight of $6000 \mathrm{t}$. Yang et al. [9] introduced the construction process of the T2 terminal building of Yancheng Nanyang Airport. The T2 terminal building of Yancheng Nanyang Airport has a large span and it was difficult to assemble the roof trusses. According to the project characteristics, the construction scheme of the roof steel structure followed the principle of subarea and substep, with the truss lifting in segmentation. Zhang et al. [10] investigated the construction technology of the Nanjing Niushou Mountain Dendritic Structure. A new construction method, self-balancing elevating scheme, was introduced according to the special condition of the construction field. Chang et al. [11] studied the construction unloading of Datong steel roof and introduced the monitoring technology of unloading to guarantee the construction safety. Li et al. [12] analyzed the vertical deformation of Shenzhen Ping'an Financial Center and the influence of the construction process on the difference of the vertical deformation of the inner and outer structures.
While the previous studies focus on the above-ground structures, there were few studies that focus on the structures built in an abandoned mine. In this paper, the Intercontinental Shanghai Wonderland is taken as an engineering background, with a complex built environment, a new structure system, and difficulties in building materials transportation and construction. According to the project characteristics, the construction technology of the Intercontinental Shanghai Wonderland was analyzed from the aspects of cliff stability analysis, structural system seismic performance, and construction method.

\section{Engineering Situation}

The Intercontinental Shanghai Wonderland is located in the abandoned mine pit of Tianma Mountain in Songjiang District, an ancient city in the western suburbs of Shanghai. The mine pit is approximately elliptical, with an east-west length of about $280 \mathrm{~m}$ and a north-south width of about $220 \mathrm{~m}$. The most profound depth of the pit is $88 \mathrm{~m}$, and the slope foot of the deep pit cliff is about $80^{\circ}$, as shown in Figure 1.

The Intercontinental Shanghai Wonderland project covers an area of $105,350 \mathrm{~m}^{2}$. It consists of a five-star hotel and associated buildings with a total construction area of $62,171.9 \mathrm{~m}^{2}, 16$ floors in the pit (including 2 underwater floors), and 2 floors above the pit. According to the mine pit construction environment, a new type of two-point support structure is adopted. The main building in the pit is fixed to the weakly weathered bedrock at the bottom of the pit through a block box foundation. Meanwhile, the steel truss is connected to the bedrock at the top of the pit by hinged bearings. The main structure is a steel frame structure system with supports, composed of the main tower structure and the apron structure. The typical building layout diagrams are shown in Figures 2-4.

Due to the particularity of the construction environment, this project needed to solve the following difficulties:

(1) The Intercontinental Shanghai Wonderland is located in an abandoned mine pit. The building is close to the cliff, and the nearest place is only $1 \mathrm{~m}$ away from the cliff. The cliff slope has a height of more than $80 \mathrm{~m}$, which belongs to the super slope. The stability of the cliff slope has an important impact on the safety of buildings and personnel. It is necessary to analyze and evaluate the stability of the cliff slope to ensure that the super slope is safe and reliable

(2) The main building in the pit is fixed to the weakly weathered bedrock at the bottom of the pit through a block box foundation. Meanwhile, the steel truss is connected to the bedrock at the top of the pit by hinged bearings. Therefore, the mechanical characteristics of the structure under horizontal load are not typical "cantilever beam" characteristics in highrise buildings. It shows a special "simply supported beam" characteristic with one end fixed and the other end hinged. Seismic waves will be transmitted to the main structure through the base rock of the pit 


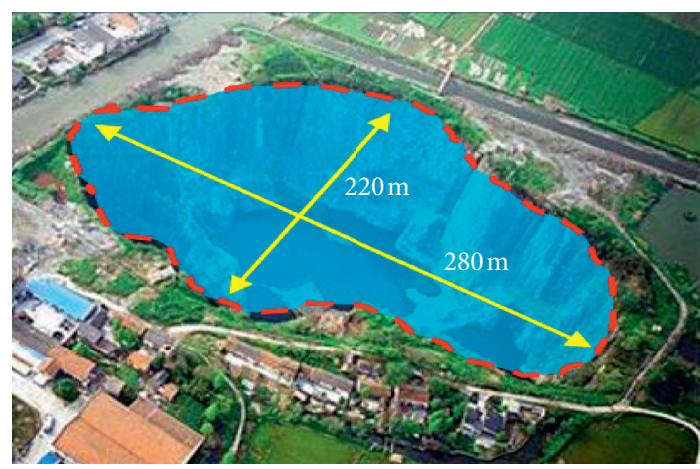

(a)

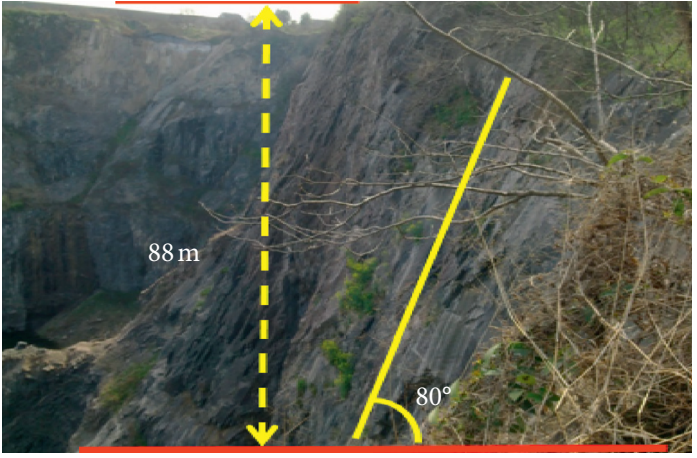

(b)

Figure 1: Overview of the abandoned mine pit. (a) Schematic plan of the abandoned mine pit. (b) The slope foot of the abandoned mine pit.
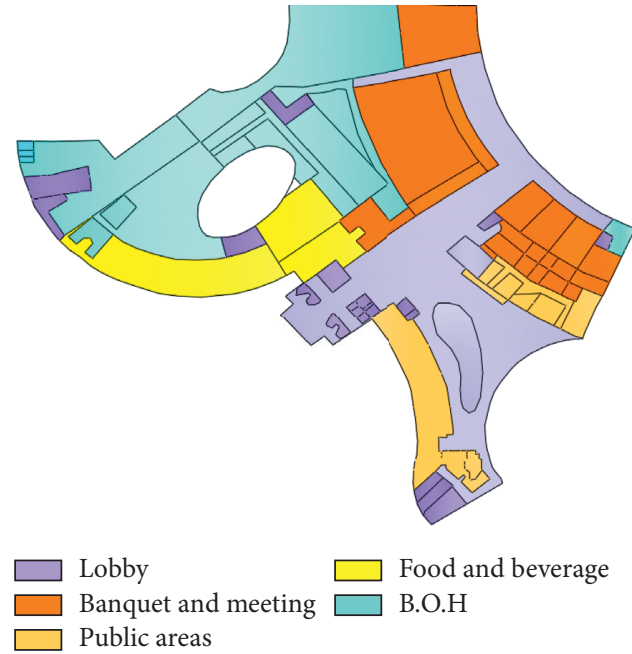

(a)
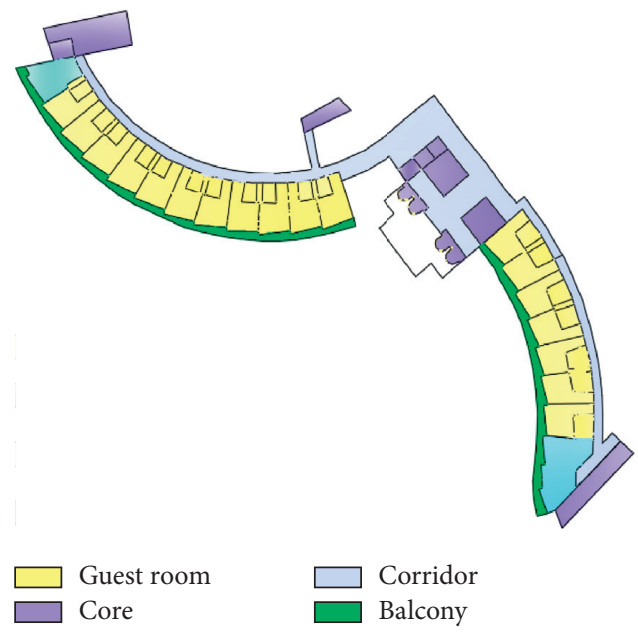

(c)

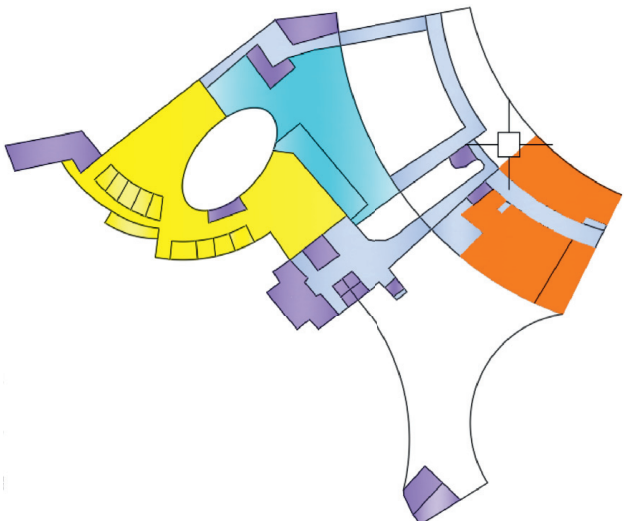

Banquet and meeting

Food and beverage

B.O.H

(b)

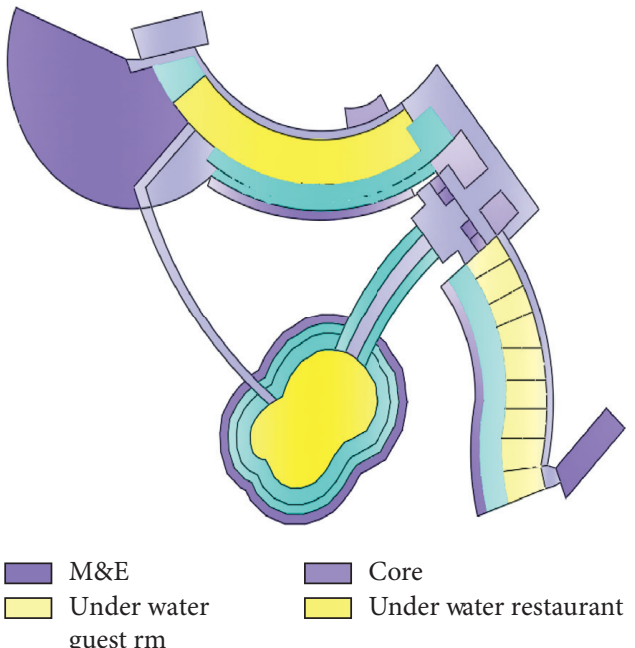

(d)

FIgURE 2: The floor plan of the building. (a) Floor plan of the first floor outside the pit. (b) Floor plan of the second floor outside the pit. (c) Standard floor plan in the pit. (d) Floor plan of B14 floor in the pit.

bottom and the top of the pit. The conventional calculation method of seismic action does not apply to this project
(3) The amount of concrete foundation at the bottom of the pit exceeds $50,000 \mathrm{~m}^{3}$. The concrete transportation had to be carried down the cliff for $80 \mathrm{~m}$ 


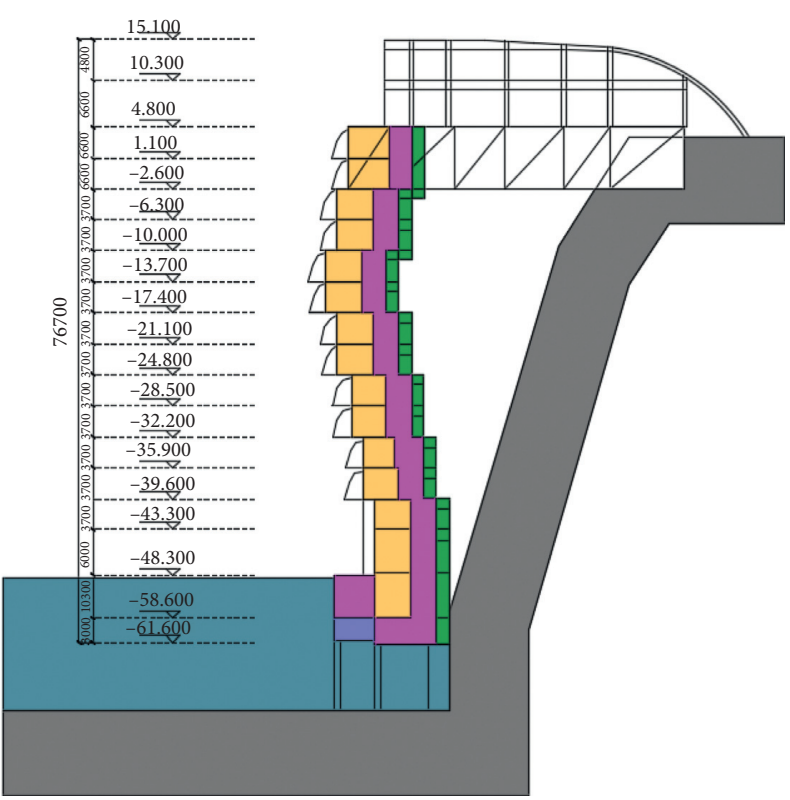

(a)

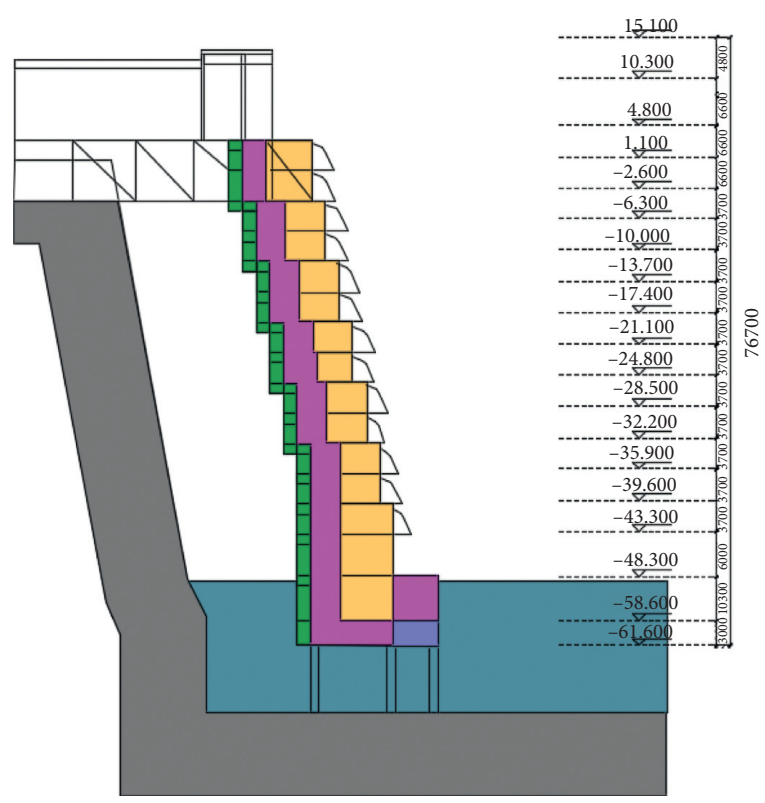

(b)

Figure 3: The profile of the building (unit: m). (a) North elevation of the building. (b) South elevation of the building.

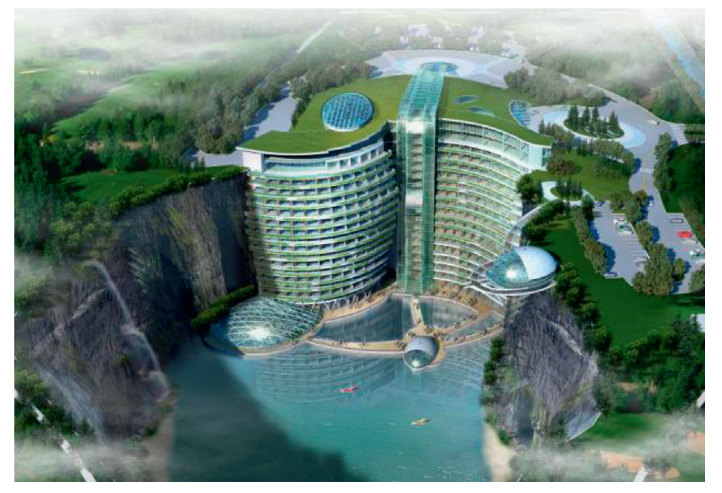

(a)

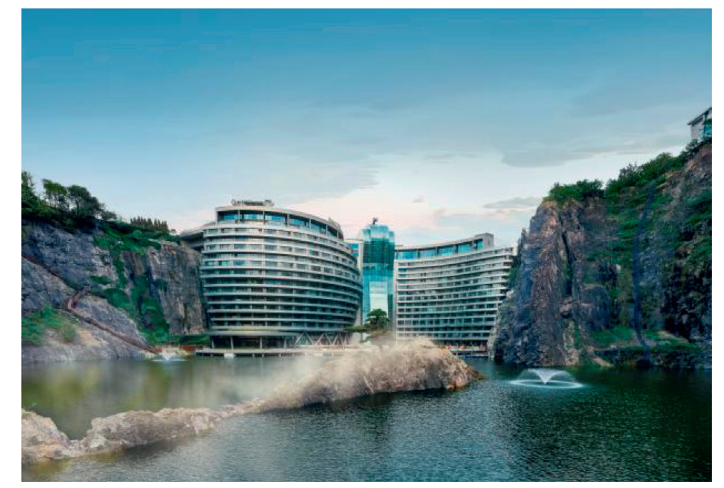

(b)

FIGURE 4: 3D rendering and actual photograph of the building. (a) 3D rendering of the building. (b) Actual photograph of the building.

and then horizontally transported $200 \mathrm{~m}$ at the bottom. The concrete transportation process is easy to block the pipe and segregate. Due to the steep cliff, people and vehicles could not pass through, which made it challenging to transport concrete. The main steel structure is a hyperbolic structure, with a maximum vertical inclination of $23^{\circ}$. The construction process required high stress and deformation control. The total steel used for the structure is about 6846 tons, and the heaviest single component is 32 tons. Moreover, the construction site was limited, which made the construction difficult

\section{Key Construction Technology of the Intercontinental Shanghai Wonderland}

3.1. Stability Analysis of Deep Pit Cliff. The Intercontinental Shanghai Wonderland is located in an abandoned mine pit with a depth of $80 \mathrm{~m}$. After years of weathering, the cliff surface has been completely weathered, as shown in Figure 5. To ensure the stability of the slope of the main building during construction and operation, the geological structure of mine pit was investigated and analyzed. The surveyed area was divided into 4 areas. The hotel project is located in area No. 3, as shown in Figure 6.

The investigation results showed that there were nearly east-west compressive and torsional microfaults on the south side of the mine pit, with a dip angle of $195^{\circ}$. They are composed of mylonite and mylonitized broken rock where chloritization and clayization are common. The rock types in the four areas surveyed in the abandoned pit were all neutral volcanic lava, which was dense in lithology and mainly composed of andesite. There was a small amount of horn flash andesite and quartz andesite. They were fully weathered andesite, strongly weathered andesite, moderately weathered andesite, and slightly weathered andesite. There was a tiny 


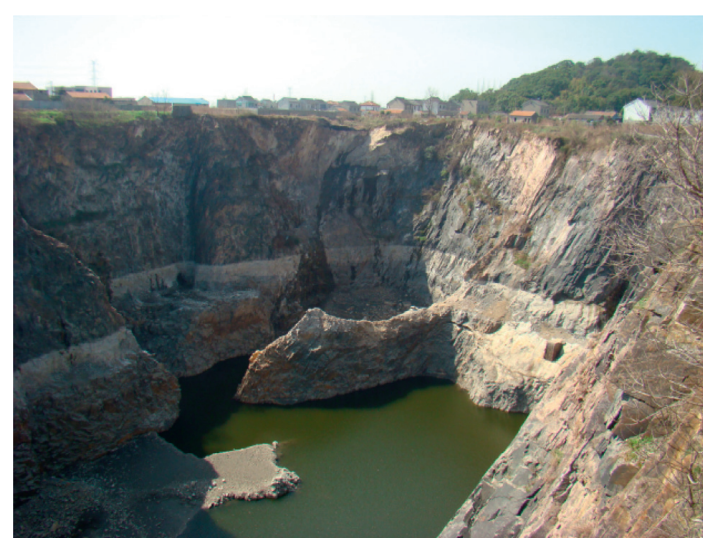

(a)

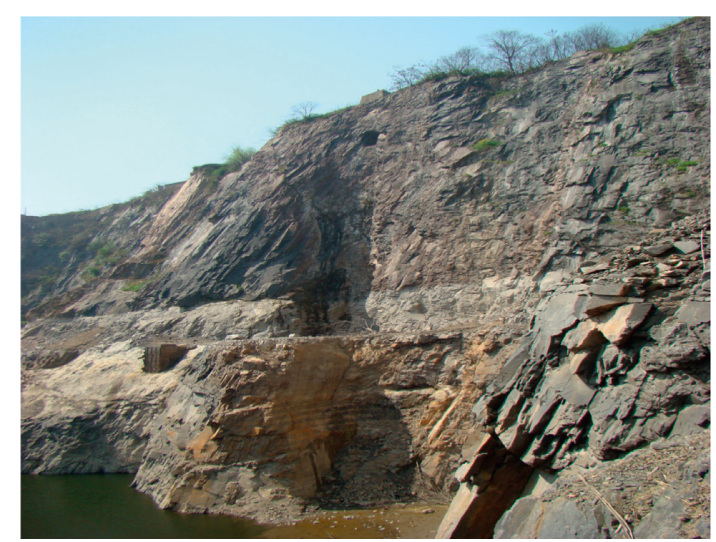

(b)

Figure 5: Original landscape of the mine. (a) Primitive cliff. (b) Cliff fragmentation.

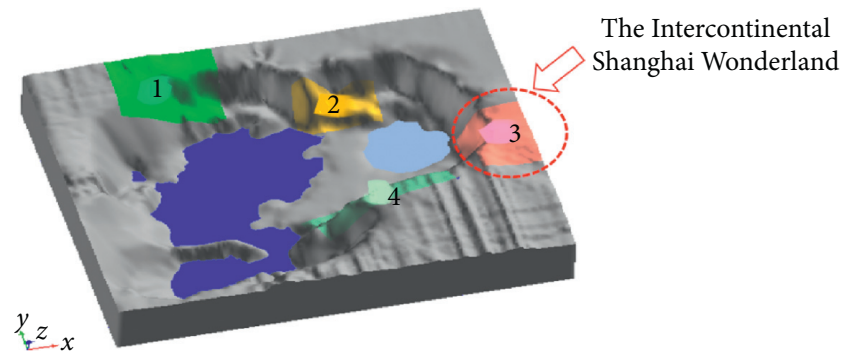

Figure 6: Schematic diagram of the survey area.

fault with a large dip angle in the No. 3 area where the project is located.

According to the geological conditions of the deep pit, the slope support was supported by prestressed anchor cables, anchor bolt, and sprayed concrete. Prestressed anchor cable supports were adopted in the range of slope elevation 0 to $11.5 \mathrm{~m}$, and sprayed concrete was applied on the surface. The prestressed anchor cables adopted unbonded free anchor cables with a bore diameter of $170 \mathrm{~mm}$, designed prestress of $750 \mathrm{kN}$ to $1750 \mathrm{kN}$, and total lengths of $15 \mathrm{~m}$ to $35 \mathrm{~m} .2000$ prestressed anchor cables were used in total. The drilling diameter of the anchor bolt was $100 \mathrm{~mm}$. The support at the bottom of the slope used an anchor bolt with a diameter of $25 \mathrm{~mm}$. The support for the strong weathering layer used an anchor bolt with a diameter of $30 \mathrm{~mm}$. The total number of the $25 \mathrm{~mm}$ anchor bolt was 2988, and the $30 \mathrm{~mm}$ anchor bolt was 9789, as shown in Figure 7.

The stability of the pit slope is critical because it directly affects the safe use of buildings in the pit. To truly reflect the $3 \mathrm{D}$ stress state of the pit, a 3D dynamic finite element method was used to establish a 3D solid mechanical model of the pit. The dynamic response characteristics of the slope under earthquake action and the instability characteristics of the slope were then analyzed.

3.1.1. Finite Element Model. The Abaqus software is used to carry out the mode analyzing calculation, and the 3D finite element model is shown in Figure 8. The entire model was

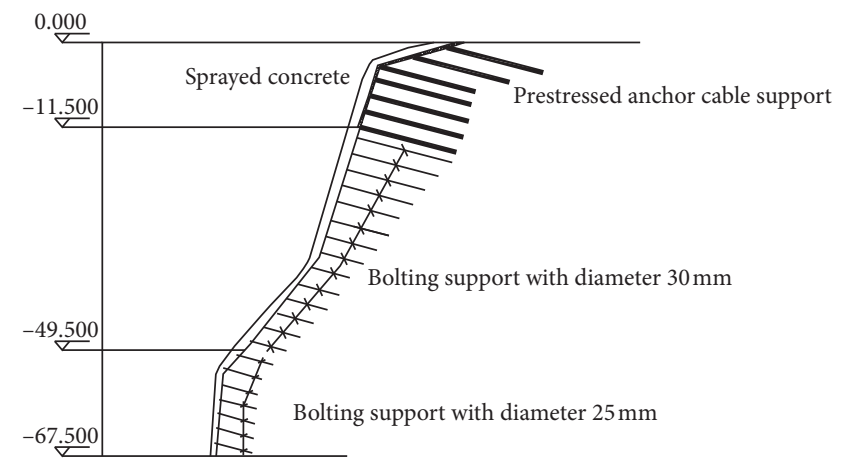

FIGURE 7: Schematic diagram of the slope support profile (unit: $\mathrm{m}$ ).

$130 \mathrm{~m}$ high, $677.4 \mathrm{~m}$ long, and $626 \mathrm{~m}$ wide. For earthquake response analysis, the boundary of the model is an infinite element, the total number of elements was 247867, and the total number of nodes was 253779. The mesh elements around the pit were densely divided, and the maximum size of the elements was not more than $2 \times 2 \times 2 \mathrm{~m}$. The total number of units in the dense range was 185729 .

As shown in Figure 9, the slope surface of the pit was modeled according to the actual situation on-site. The model was built according to the fault information documented in the geological survey report. The faults in the mine pit were considered in the finite element model. To simulate the actual situation of the bottom of the pit, the three partial protrusions at the bottom of the pit were also simulated in the finite element. The green unit in the finite element model was the fault weakening layer. The top elevation of the model was $+0 \mathrm{~m}$. The bottom elevation of the pit was $-80 \mathrm{~m}$. The bottom elevation of the model was $-130 \mathrm{~m}$. The profile of the pit model is shown in Figure 10. The first layer of the pit was miscellaneous fill, as shown in the yellow unit. The second layer was grey clay, as shown in off-white. The third layer was yellow clay, as shown in red. The fourth layer was the middle-weathered rock, as shown in black. The fifth layer was slightly weathered rock, as shown in white. The thickness of the upper three layers of soil L was $38 \mathrm{~m}$. The total height of the five layers $\mathrm{H}$ was $130 \mathrm{~m}$. The material properties are shown in Table 1. 


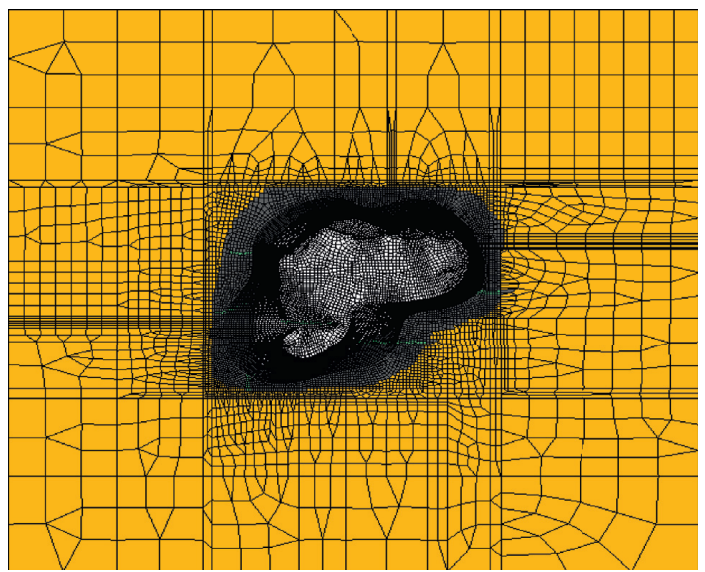

Figure 8: Schematic diagram of the finite element model.

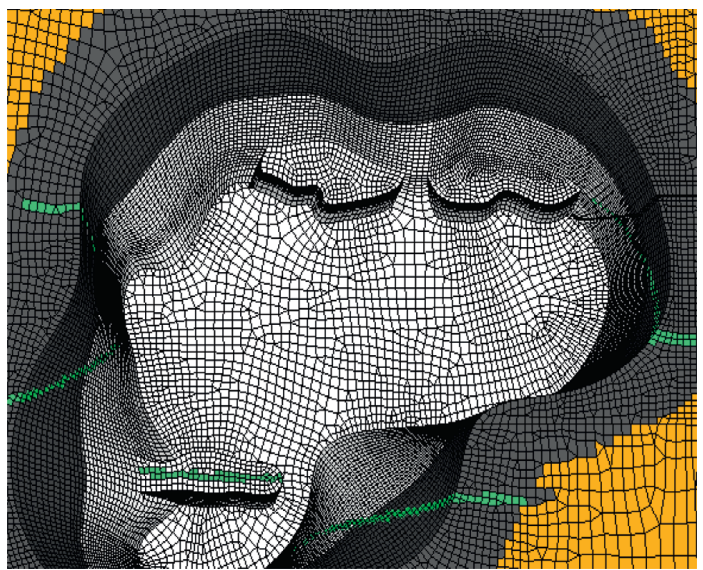

FIgURE 9: Schematic detail of the pit bottom.

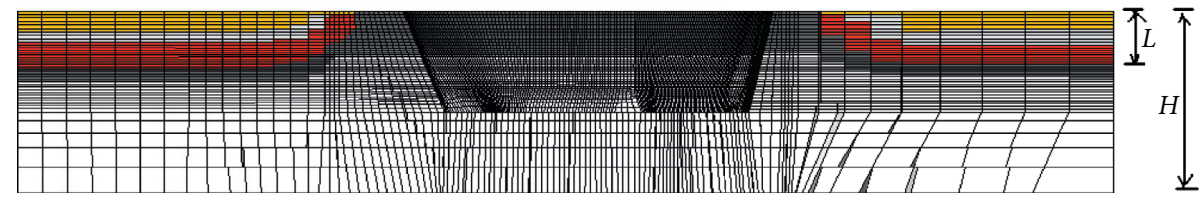

Figure 10: The profile diagram of the FEA model.

TABle 1: The material property.

\begin{tabular}{lccccc}
\hline No. & Material type & $\mu$ & $\gamma\left(\mathrm{kN} / \mathrm{m}^{3}\right)$ & $\mathrm{E}(\mathrm{GPa})$ & $c(\mathrm{MPa})$ \\
\hline 1 & Miscellaneous fill layer & 0.37 & 19.2 & 0.088 & 0.018 \\
2 & Grey clay layer & 0.30 & 19.0 & 0.119 & 0.025 \\
3 & Yellow clay layer & 0.30 & 18.8 & 0.351 & 16.0 \\
4 & Middle-weathered rock & 0.28 & 28.0 & 4.11 & 0.073 \\
5 & Slightly weathered rock & 0.28 & 28.0 & 4.39 & 0.75 \\
6 & Anchor bolt & 0.3 & 78.0 & 210 & 1.04 \\
\hline
\end{tabular}

To simulate the reinforcement effects of anchor bolts on the pit, the anchor bolts were simulated as link elements. Further, the pretension force was applied to the link elements to simulate the prestress loading effects, as shown in Figure 11.
3.1.2. Finite Element Calculation Results. The static load was applied to the 3D model, and the calculated result was taken as the initial stress state of the model. Then, under the conditions of no support and anchoring support, the overall stability of the pit with three working cases was investigated. 


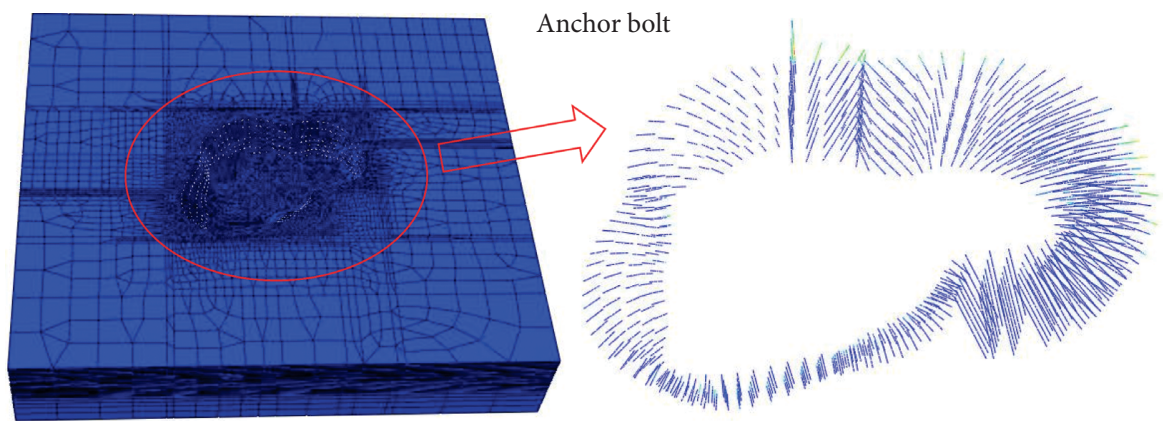

FIGURE 11: Schematic diagram of anchor bolt in the FEA model.

There different cases, static overload, small earthquake, and large earthquake, were considered, as shown in Table 2.

In the static overload calculation, the load includes the dead weight of the structure and the overload of the upper structure. In the earthquake responses' analysis, the maximum input acceleration value is 180 gal in the large earthquake state and $34 \mathrm{gal}$ in the small earthquake state. This was done by applying seismic action in the horizontal direction at the bottom of the model. Based on the calculation results of large earthquakes, the calculation results were analyzed. Under the condition of no support, the maximum total displacement was $150 \mathrm{~mm}$, which appeared on the boundary of the pit. The maximum displacement around the pit was $40 \mathrm{~mm}$. The maximum stress was 5.4 MPa, and the area of greater stress was at the bottom of the pit. Under the condition of anchoring support, the maximum displacement around the pit was $80 \mathrm{~mm}$, which appeared on the boundary of the pit. The maximum displacement around the pit was $20 \mathrm{~mm}$. The rock mass instability of the pit is judged by the equivalent plastic strain penetrating from the foot to the top of the slope. Under the condition of no support (factor of safety $F s=1.0$ ), the equivalent plastic strain of the pit penetrated from the foot of the slope to the top of the slope, and the pit reached an unstable state. Under the conditions of anchoring support (factor of safety Fs $=1.4$ ), the equivalent plastic strain of the pit penetrated from the foot of the slope to the top of the slope. The calculation results of relative displacement and stability coefficient of slope under different working conditions are shown in Table 3. The calculation results showed that with effective anchoring support measures, the stability coefficient of slope under static load and small earthquakes was large, which had a certain safety margin. Under the action of large earthquakes, the slope could still meet the stability requirements.

\subsection{Analysis of the Mechanical Performance of the Intercon-} tinental Shanghai Wonderland. The main structure is a steel frame structure system with support. The structure inside the pit is composed of two tower structures, which are connected outside the pit. Therefore, the structure was divided into three parts, including the outer part of the pit, Tower 1 in the pit, and Tower 2 in the pit, as shown in Figure 12. The seismic seam is arranged in the B13 to B2 floors between Tower 1 and Tower 2, as shown in Figure 13.
TABLe 2: The analysis cases.

\begin{tabular}{|c|c|c|}
\hline Stage & Analysis case & Support type \\
\hline 1 & Static overload & $\begin{array}{c}\text { No support } \\
\text { Anchoring support }\end{array}$ \\
\hline 2 & Small earthquake & $\begin{array}{c}\text { No support } \\
\text { Anchoring support }\end{array}$ \\
\hline 3 & Large earthquake & $\begin{array}{c}\text { No support } \\
\text { Anchoring support }\end{array}$ \\
\hline
\end{tabular}

TABLE 3: Calculation result of slope stability.

\begin{tabular}{lcccc}
\hline $\begin{array}{l}\text { Working } \\
\text { conditions }\end{array}$ & \multicolumn{2}{c}{ Displacement $(\mathrm{mm})$} & \multicolumn{2}{c}{ Factor of safety } \\
sopport & $\begin{array}{c}\text { Anchoring } \\
\text { support }\end{array}$ & $\begin{array}{c}\text { No } \\
\text { support }\end{array}$ & $\begin{array}{c}\text { Anchoring } \\
\text { support }\end{array}$ \\
\hline $\begin{array}{l}\text { Static } \\
\text { overload }\end{array}$ & 0.18 & 0.1 & 1.8 & 2.0 \\
$\begin{array}{l}\text { Small } \\
\text { earthquake }\end{array}$ & 13 & 9 & 1.2 & 1.6 \\
$\begin{array}{l}\text { Large } \\
\text { earthquake }\end{array}$ & 125 & 80 & 1.0 & 1.4 \\
\hline
\end{tabular}

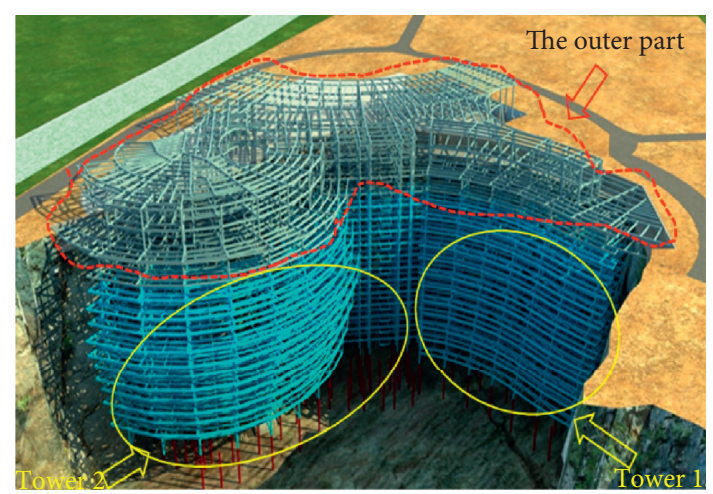

FIGURE 12: Block diagram of the building.

Supported steel frames are arranged in the guest room area. The frame columns are inclined concrete-filled steel tube columns. The main concrete-filled steel tube columns have a diameter of $600 \mathrm{~mm}$ and a thickness of $30 \mathrm{~mm}$. The concrete-filled steel tube column and steel frame beam are made of Q345. The strength of the filled concrete in the tube is $\mathrm{C} 80$. 


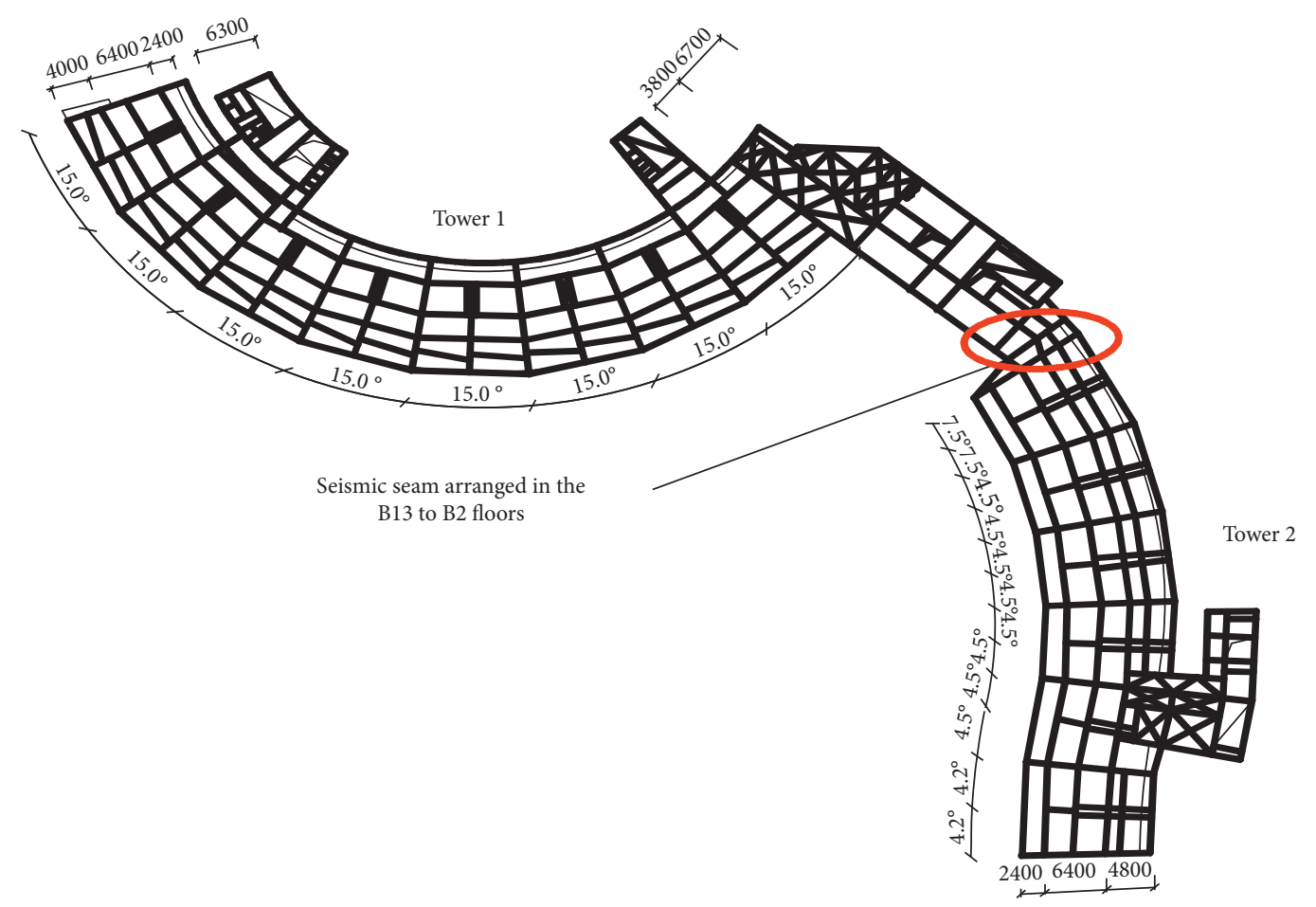

FIgUre 13: The seismic seam of the building.

\begin{abstract}
3.2.1. Modal Analysis of the Intercontinental Shanghai Wonderland. The modal analysis of the Intercontinental Shanghai Wonderland was conducted through the finite element software ETABS and MIDAS. The results of the modal analysis are shown in Table 4 . The values in parentheses are the results of MIDAS calculation. The first mode, second mode, and third mode of the outer part are $\mathrm{Y}$ translation, $\mathrm{X}$ translation, and Torsion, respectively. The first three modes of Tower 1 are $\mathrm{X}$ translation, $\mathrm{Y}$ translation, and Torsion, respectively. The first three modes of Tower 2 are $\mathrm{Y}$ translation, $\mathrm{X}$ translation, and Torsion, respectively. The vibration modes of the different parts are shown in Figures 14-16. The calculated period ratios of the first mode and third mode are tabulated in Table 4 . These ratios of the outer part, Tower 1 , and Tower 2 were $0.86,0.62$, and 0.51 , respectively, which met the specification requirements.
\end{abstract}

\subsubsection{Seismic Performance Analysis of the Intercontinental} Shanghai Wonderland. To determine whether the structure meets the antiseismic design goal (not collapsing under the action of rare earthquakes), an overall 3D model was established in Sap2000. The plastic hinge model was utilized to simulate the concrete-filled steel tube, and the parameters of the plastic hinge model adopt the unified strength theory, which was put forward by Zhong [13]. The elastoplastic time history analysis under this condition was then carried out. The bottom of the building is fixed on the foundation of the pit while the top of the building is hinged on the concrete beam at the top of the pit. The mechanical characteristics of the structure under horizontal load show a special "simply supported beam" characteristic with one end fixed and the other end hinged, as shown in Figure 17. According to the principle of seismic wave propagation, the peak acceleration of the seismic ground motion and the seismic impact coefficient of the response spectrum should be amplified compared to the base seismic motion. The height difference between the support point $\mathrm{M}$ and the support point $\mathrm{N}$ is $80 \mathrm{~m}$. The earthquake action of this project is very different from the ordinary building structure, and the response spectrum method cannot solve the problems of the seismic design of this project. Therefore, the time history analysis method was used to solve the seismic design problem of this multipoint support structure. Generally, there are two types of input seismic excitation for time history analysis of multipoint support structures. One is to use the displacement of the seismic ground motion as a dynamic load to establish a dynamic balance equation about the absolute coordinate system, which is called the displacement input model. The other is to use the acceleration of the ground motion as a dynamic load to establish the dynamic balance equation, which is called the acceleration input model. If the acceleration input model is used, the software will integrate the acceleration twice during the calculation process. This will produce two constants, namely, the initial velocity and the initial displacement. The software will not modify the constants generated during the integration process, resulting in displacement drift. Therefore, the seismic excitation input of this project adopted the displacement input model.

According to the safety assessment report, the timewaves were all artificial waves, and three sets of artificial waves were selected. The peak displacements of the three sets of artificial waves at points $\mathrm{M}$ and $\mathrm{N}$ are shown in Table 5. For each group of seismic waves, two acceleration inputs 
TABLE 4: Results of the modal analysis.

\begin{tabular}{lccc}
\hline The parts of the building & Modal no. & Period & Modal form \\
\hline \multirow{3}{*}{ The outer part } & T1 & $0.851(0.807)$ & Y translation \\
& T2 & $0.804(0.763)$ & X translation \\
& T3 & $0.732(0.681)$ & Torsion \\
\hline \multirow{3}{*}{ Tower 1 } & T1 & $0.811(0.789)$ & X translation \\
& T2 & $0.546(0.559)$ & Y translation \\
\hline \multirow{3}{*}{ Tower 2 } & T3 & $0.505(0.519)$ & Torsion \\
& T1 & $0.838(0.846)$ & Y translation \\
& T2 & $0.451(0.456)$ & X translation \\
\hline
\end{tabular}

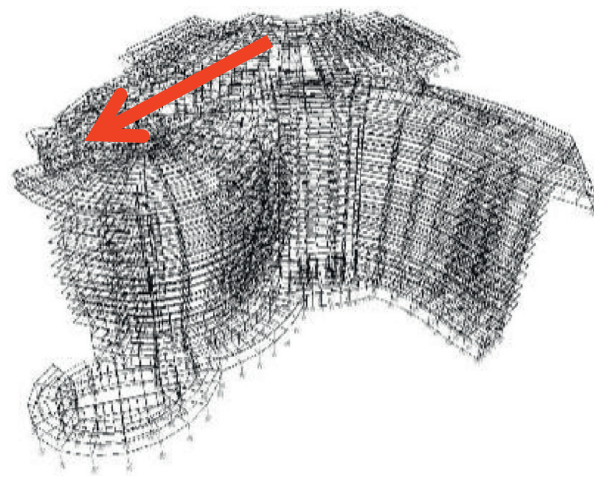

(a)

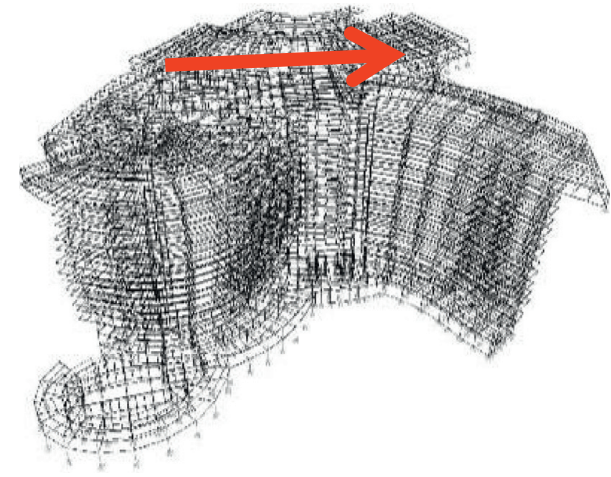

(b)

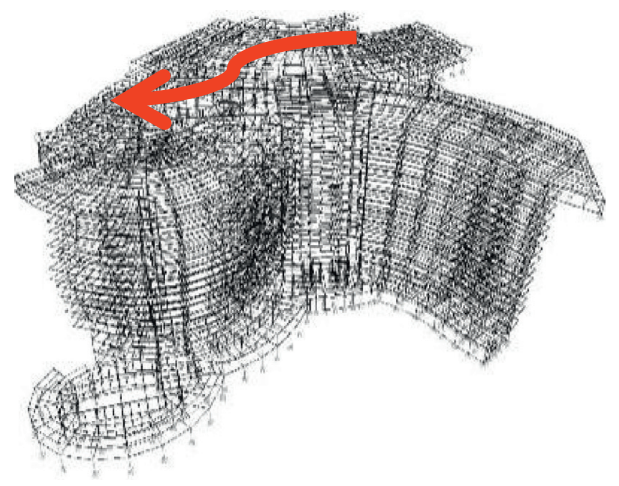

(c)

Figure 14: Vibration mode diagram of the outer part. (a) The first mode (Y translation). (b) The second mode (X translation). (c) The third mode (torsion).

were considered in $\mathrm{X}$ and $\mathrm{Y}$ directions. Three sets of seismic waves were calculated for a total of six working conditions, as shown in Table 6. Working condition 1 was No. 1 seismic wave $1.0 x+0.85 y$. Working condition 2 was No. 1 seismic wave $0.85 x+1.0 y$. Working condition 3 was No. 2 seismic wave $1.0 x+0.85 y$. Working condition 4 was No. 2 seismic wave $0.85 x+1.0 y$. Working condition 5 was No. 3 seismic wave $1.0 x+0.85 y$. Working condition 6 was No. 3 seismic wave $0.85 x+1.0 y$.

The maximum base shear forces of the tower structure under six working conditions are shown in Table 7. In the $X$ direction, the average values of the maximum base shear forces of Tower 1 and Tower 2 are $28011 \mathrm{kN}$ and $46007 \mathrm{kN}$, respectively. In the $Y$ direction, the average values of the maximum base shear forces of Tower 1 and Tower 2 are
$38192 \mathrm{kN}$ and $14807 \mathrm{kN}$, respectively. Under each working condition, the maximum layer displacement angle was within $1 / 250$, which satisfied the limit requirement of $1 / 50$ of the seismic code. Under the working conditions 1 and 2, some concrete-filled steel tubular columns produced plastic hinge at the bottom of the structure and the connection between the top structure and span truss. However, there was no plastic hinge that occurred in the steel supports and steel beams. Further, no component produced plastic hinge under working conditions 3 and 4 . Under working conditions 5 and 6 , some concrete-filled steel tubular columns produced plastic hinge at the bottom of the structure, some steel supports produced plastic hinge at the top of the structure, and no plastic hinge occurred in the steel beams. The distribution of plastic hinges is shown in Figure 18. 


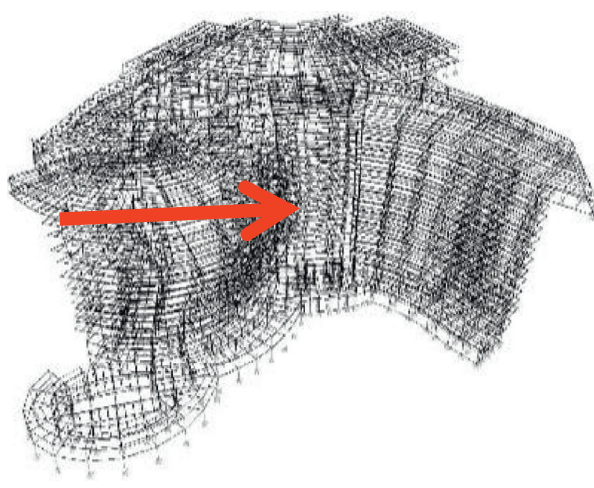

(a)

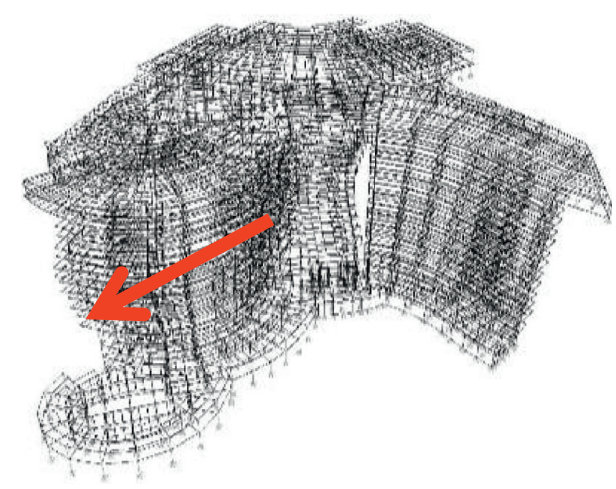

(b)

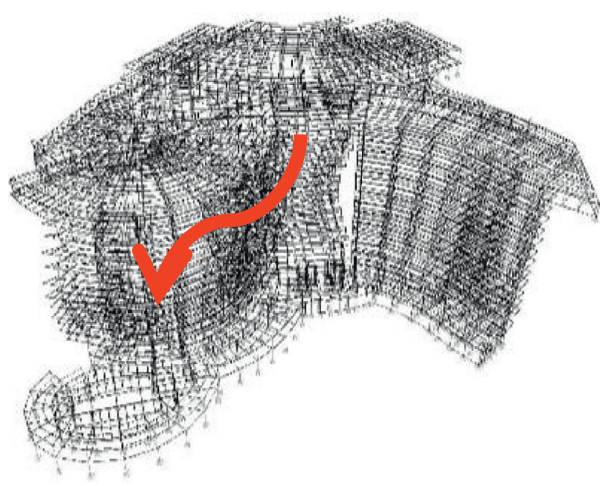

(c)

Figure 15: Vibration mode diagram of Tower 1. (a) The first mode (X translation). (b) The second mode (Y translation). (c) The third mode (torsion).

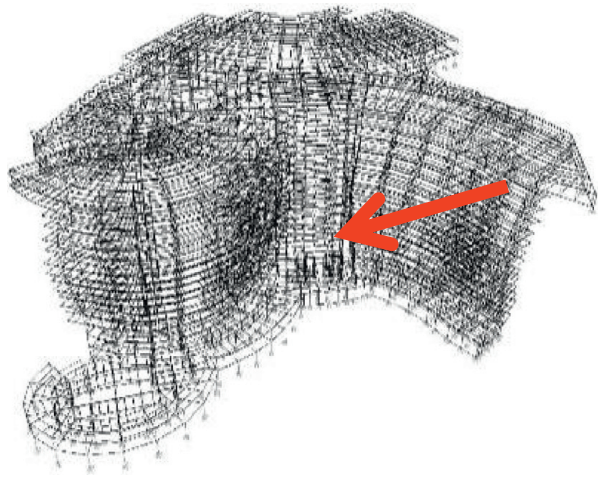

(a)

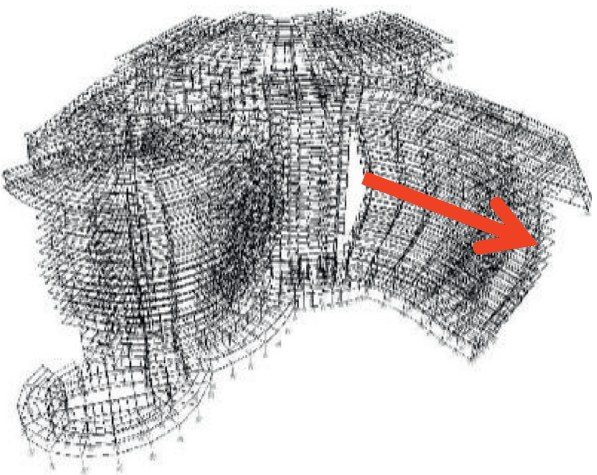

(b)

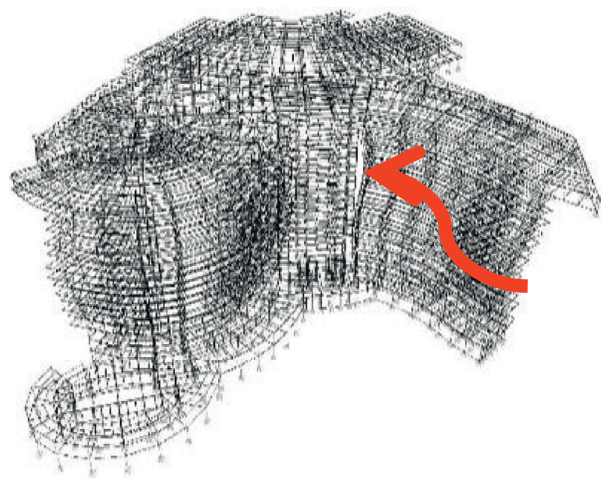

(c)

Figure 16: Vibration mode diagram of Tower 2. (a) The first mode (Y translation). (b) The second mode (X translation). (c) The third mode (torsion). 


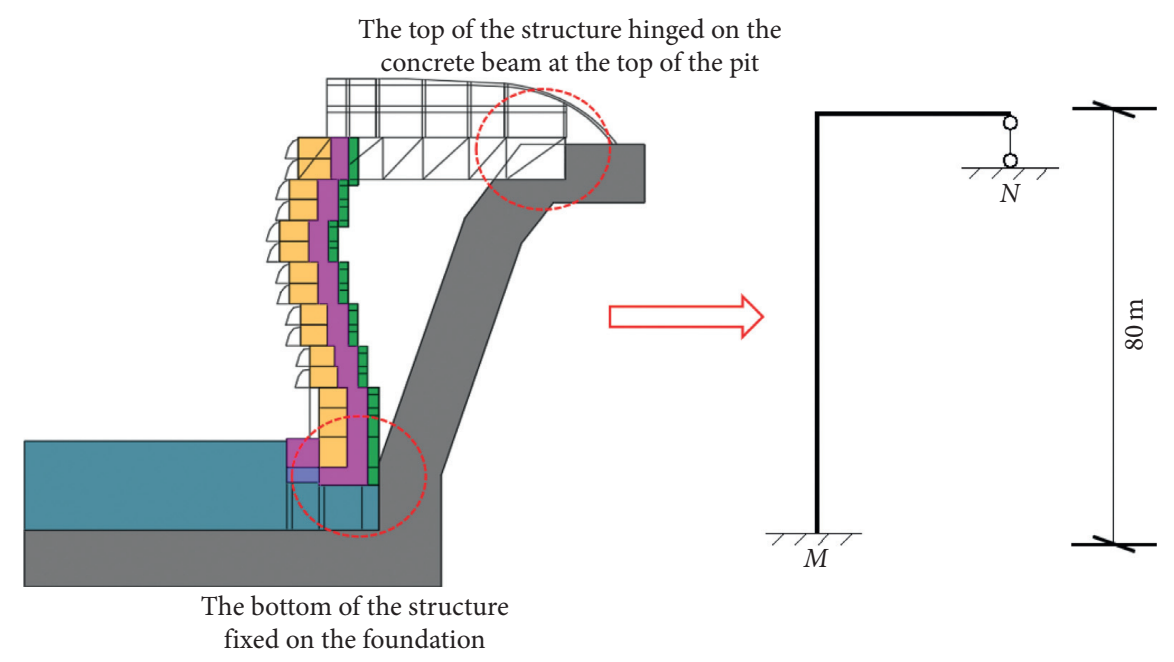

FIGURE 17: Simplified structure force diagram (unit: $\mathrm{m}$ ).

TABle 5: The peak displacement of different seismic waves at points $\mathrm{M}$ and $\mathrm{N}$.

\begin{tabular}{lrr}
\hline The time history curve no. & $N$ & The peak displacement (m) \\
\hline No.1 & 0.1089 & 0.0507 \\
No.2 & 0.1134 & 0.0532 \\
No.3 & 0.1237 & 0.0602 \\
\hline
\end{tabular}

TABLE 6: Working conditions.

\begin{tabular}{lll}
\hline The time history curve no. & Working condition & Load combination \\
\hline \multirow{2}{*}{ No. 1} & Working condition 1 & No. 1 seismic wave $1.0 x+0.85 y$ \\
& Working condition 2 & No. 1 seismic wave $0.85 x+1.0 y$ \\
\multirow{2}{*}{ No. 2} & Working condition 3 & No. 2 seismic wave $1.0 x+0.85 y$ \\
& Working condition 4 & No. 2 seismic wave $0.85 x+1.0 y$ \\
\multirow{2}{*}{ No. 3} & Working condition 5 & No. 3 seismic wave $1.0 x+0.85 y$ \\
& Working condition 6 & No. 3 seismic wave $0.85 x+1.0 y$ \\
\hline
\end{tabular}

TABLE 7: Maximum base shear force under various working conditions.

\begin{tabular}{lcccc}
\hline Working condition no. & \multicolumn{2}{c}{ X direction } & \multicolumn{2}{c}{ P Direction } \\
& Tower 1 $(\mathrm{kN})$ & Tower 2 $(\mathrm{kN})$ & Tower 1 $(\mathrm{kN})$ & Tower 2 $(\mathrm{kN})$ \\
\hline No. 1 & 29528 & 29193 & 51704 & 18831 \\
No. 2 & 25840 & 31570 & 47680 & 20841 \\
No. 3 & 26478 & 37001 & 41523 & 13316 \\
No. 4 & 23224 & 40747 & 38192 & 14807 \\
No. 5 & 33521 & 41378 & 39567 & 13076 \\
No. 6 & 29473 & 46007 & 36319 & 14309 \\
Average value & 28011 & 37649 & 42498 & 15863 \\
\hline
\end{tabular}

The compressive yield strain of concrete-filled steel tube columns was about $0.12 \%$, and the ultimate compressive strain exceeded $1 \%$. The strain time curves of the typical bottom concrete-filled steel tube column with plastic hinge under condition 1 and condition 2 are shown in Figures 19 and 20, respectively. The maximum plastic strain of concrete-filled steel tube columns was only $0.16 \%$, which had just exceeded the compressive yield strain of $0.12 \%$. This was far from reaching the ultimate compressive strain of $1 \%$. It was indicated that the concrete-filled steel tube column has just entered plasticity under a rare earthquake, and the degree of plasticity was low. Therefore, the current structural system along with the design of component size and strength can meet the seismic performance of the structure under actions of rare earthquakes. 

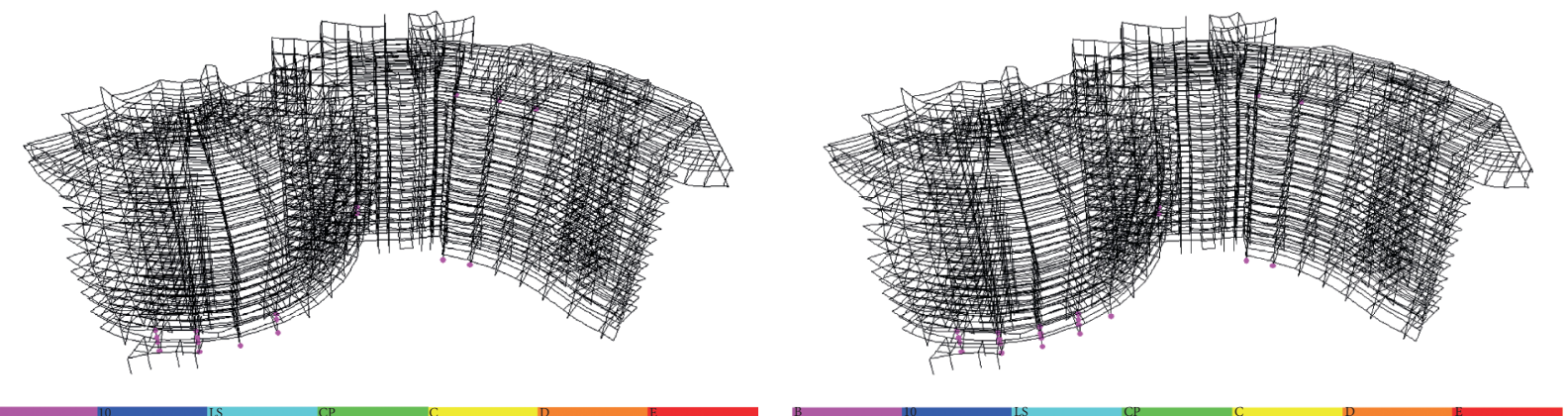

(a)

(b)

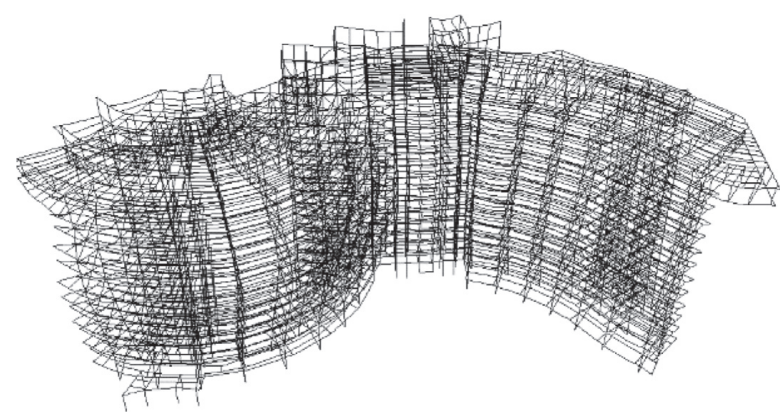

(c)

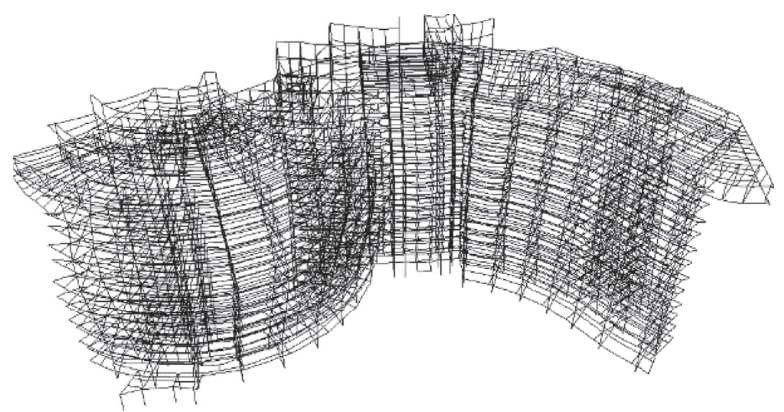

(d)

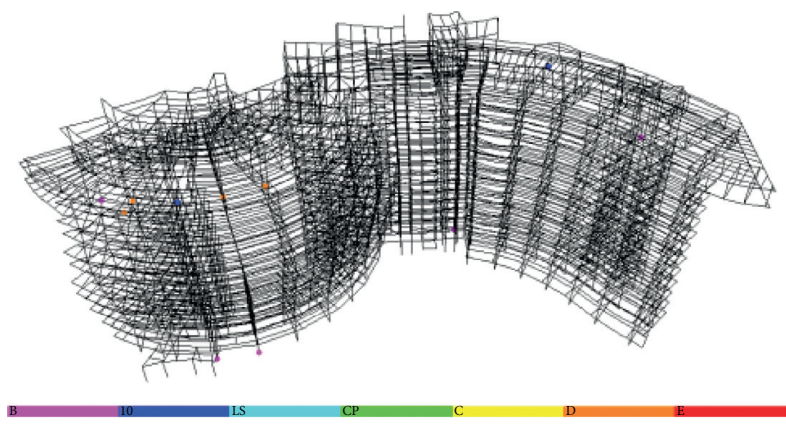

(e)

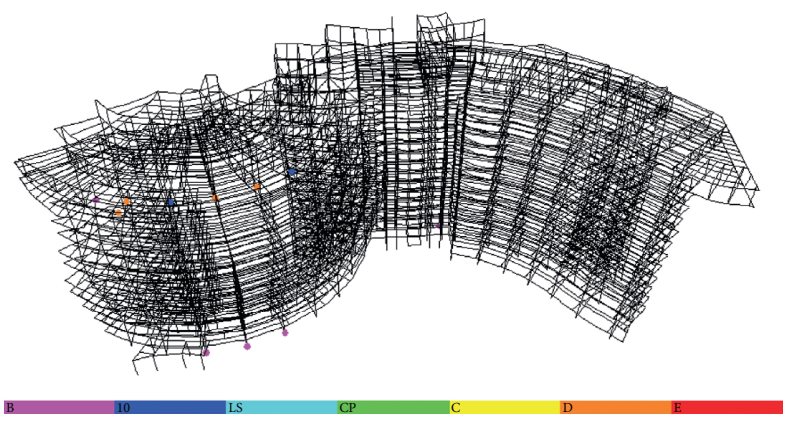

(f)

Figure 18: Schematic diagram of plastic hinge distribution. (a) Condition 1. (b) Condition 2. (c) Condition 3. (d) Condition 4. (e) Condition 5. (f) Condition 6.

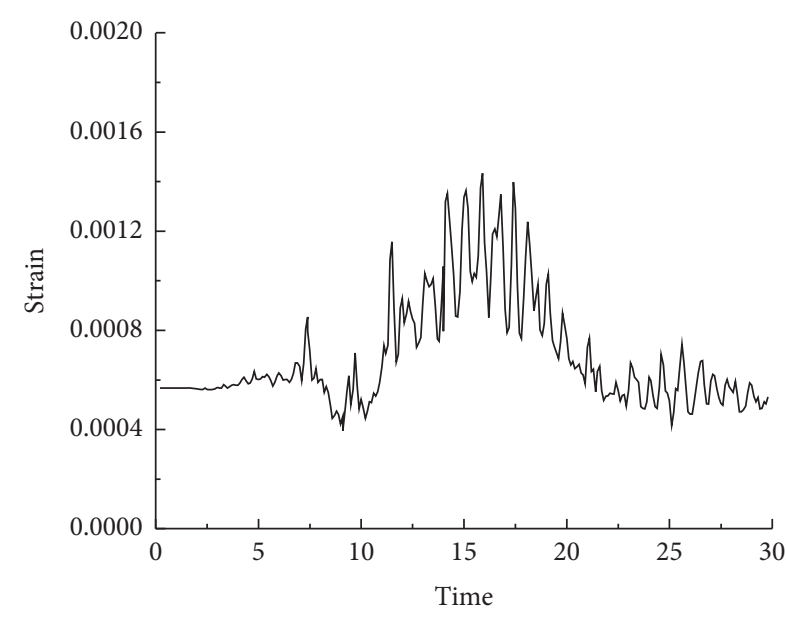

(a)

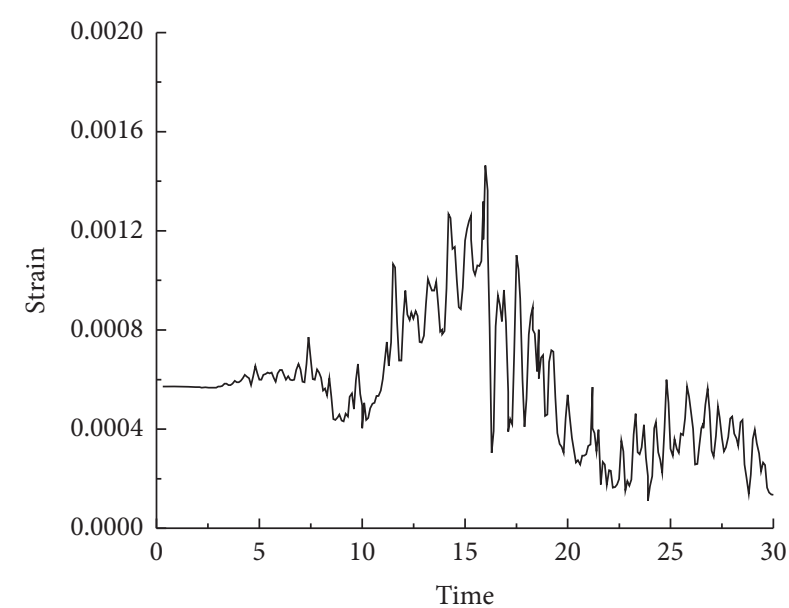

(b)

Figure 19: The strain time curves of the typical bottom concrete-filled steel tube column of Tower 1 with a plastic hinge. (a) Condition 1. (b) Condition 2. 


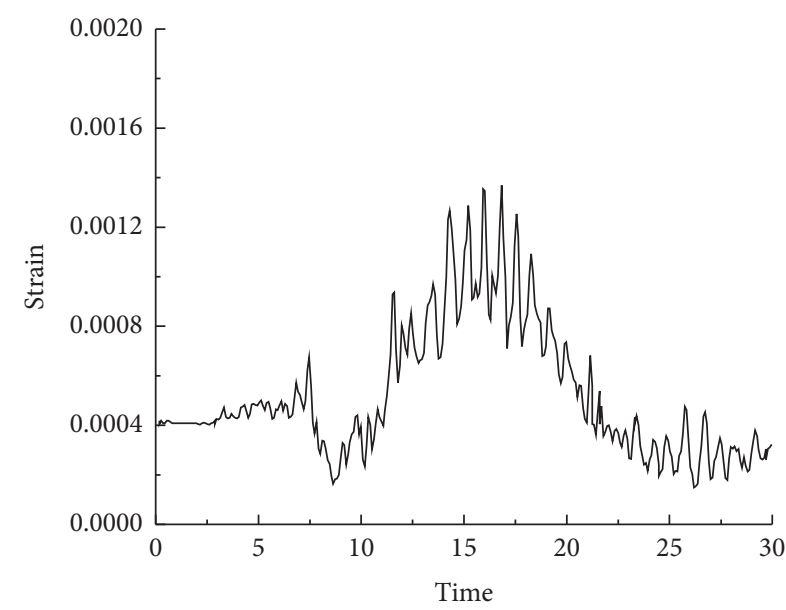

(a)

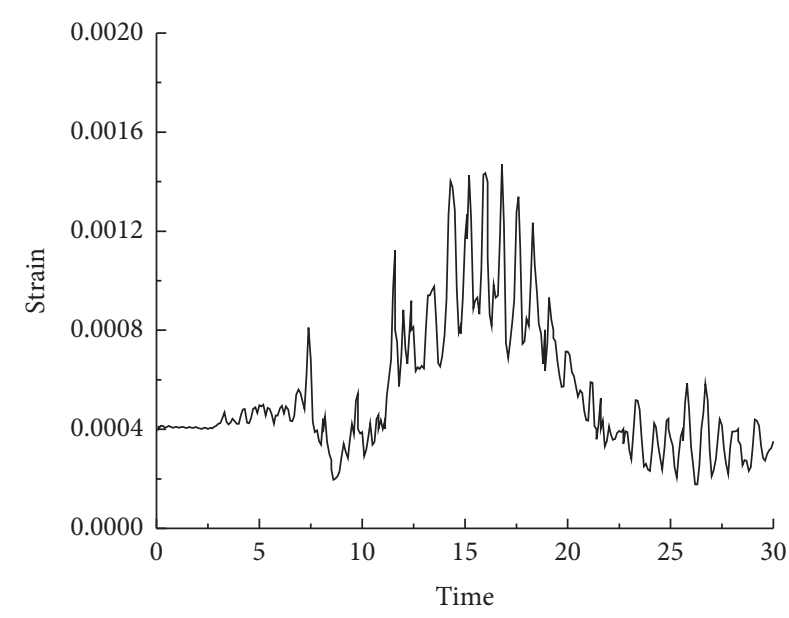

(b)

Figure 20: The strain time curves of the typical bottom concrete-filled steel tube column of Tower 2 with a plastic hinge. (a) Condition 1. (b) Condition 2.

\subsection{Construction Technology of Intercontinental Shanghai Wonderland}

\subsubsection{Construction Technology of Downward Ultradeep} Concrete Transportation. The deep pit hotel is built in a steep deep pit where the bottom of the pit is complex. Meanwhile, the height difference is large; therefore, the bottom of the pit was designed as a backfill concrete foundation. The bottom of the pit was first leveled with large-volume concrete with a strength of C25. Then, the column cap and two-layer box foundation were constructed. The large-volume backfill concrete foundation at the bottom of the pit was terraced, and the elevation was strewn at random and complex. There were 12 different step elevations, with the highest height of $19 \mathrm{~m}$, as shown in Figure 21. The backfill concrete pouring started from low to high according to the height of steps and the terrain. Due to the large area, the backfill concrete was divided into the left and right pieces for construction. The whole pouring process was divided into 12 times, and the height of each pouring was controlled within $2 \mathrm{~m}$.

The amount of backfilled concrete at the bottom of the pit reached $54431 \mathrm{~m}^{3}$. The concrete transportation needed to be transported down $80 \mathrm{~m}$ on the nearly straight wall slope first and then transported horizontally to the range of about $200 \mathrm{~m}$ at the bottom of the pit. When the concrete is transported down to a distance of $80 \mathrm{~m}$ at a sloping foot of about $80^{\circ}$, it is easy to produce concrete segregation and pipe blockage. Besides, the cliff slope had an irregular section, and the surface was weathered rock, which increased the transportation difficulty of concrete. Therefore, it is difficult to transport concrete in pits by conventional means of transport. To solve the difficulty of concrete transportation at the bottom of the pit, a new type of conveying device was invented. It was composed of three parts including a buffer hopper, a buffer device, and a buffer discharge port, as shown in Figure 22.

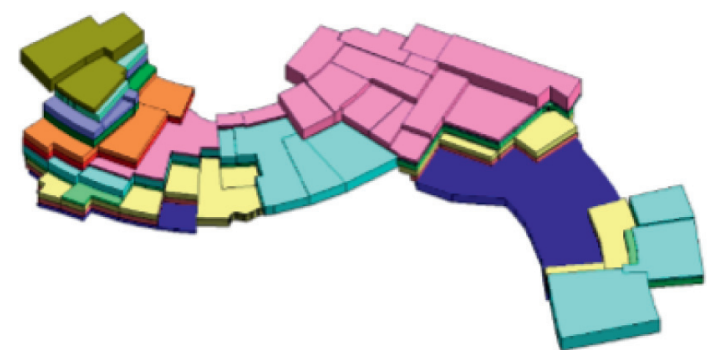

FIGURE 21: Schematic diagram of the backfill concrete foundation at the bottom of the pit.

3.3.2. Construction Technology of Hyperbolic Complex Steel Frame Structure. The engineering structure of the Intercontinental Shanghai Wonderland is a steel frame structure system with support. The building is divided into Zone A and Zone B, where the profile of Zone A is a two-way roll structure, and the profile of Zone B is a one-way roll structure, as shown in Figure 23. The total steel used for the structure is about 6846 tons, and the heaviest single component is 32 tons. The main steel structure is a hyperbolic structure with a maximum vertical inclination of $23^{\circ}$. The construction process required high stress and deformation control. Moreover, the construction site area was limited, which increased the difficulty of construction.

The whole construction process was mainly divided into 17 construction steps. Taking the typical steel frame TR3A in Zone $\mathrm{A}$ as an example, the construction steps are shown in Figure 24 .

To ensure the safety of the construction process, the construction process of the structure was simulated by finite element software MIDAS GEN to obtain the mechanical properties of the structure. The FEA model of the structure is shown in Figure 25. The changes in maximum displacement and internal force of members under each load step are shown in Figures 26 and 27. 


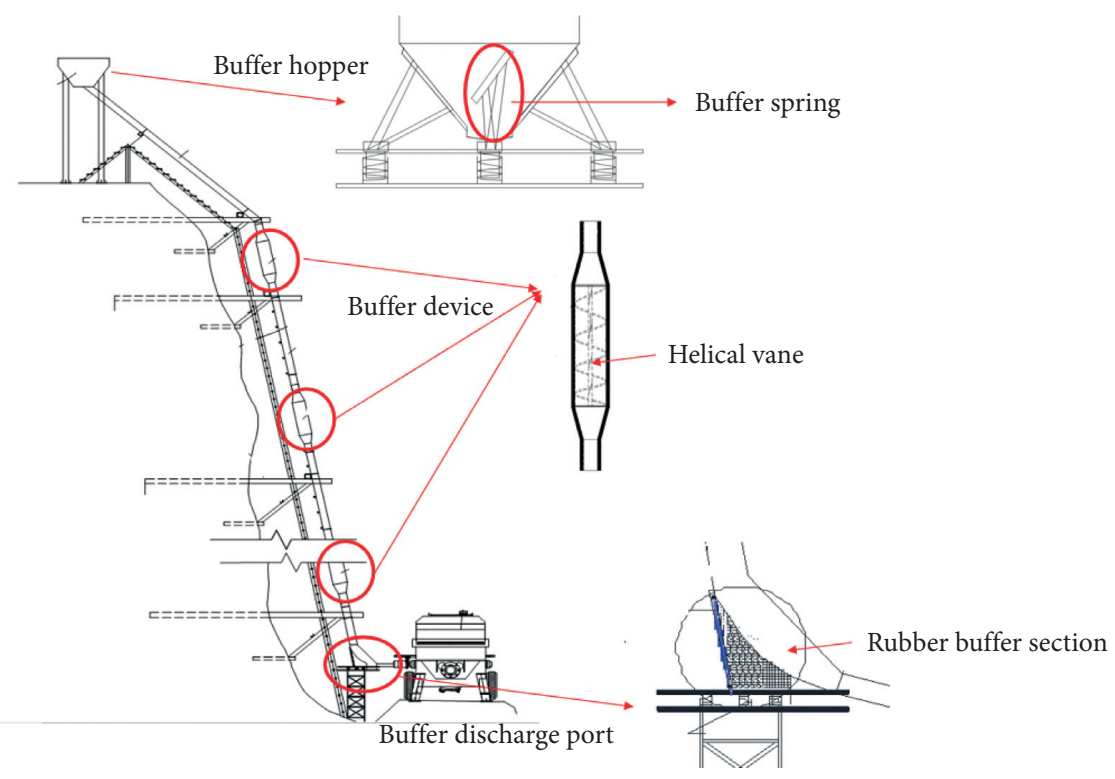

Figure 22: Concrete conveying device.

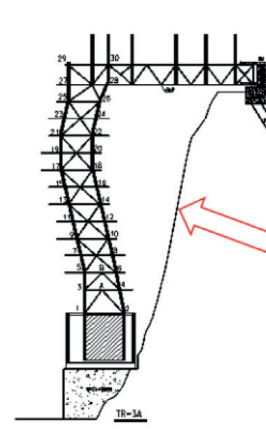

Structural profile of zone A
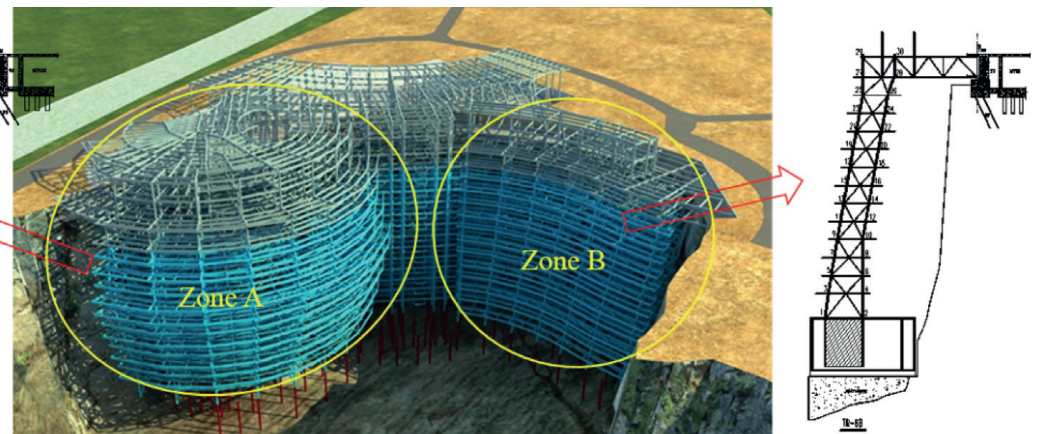

Structural profile of zone B

Figure 23: Schematic diagram of the building.

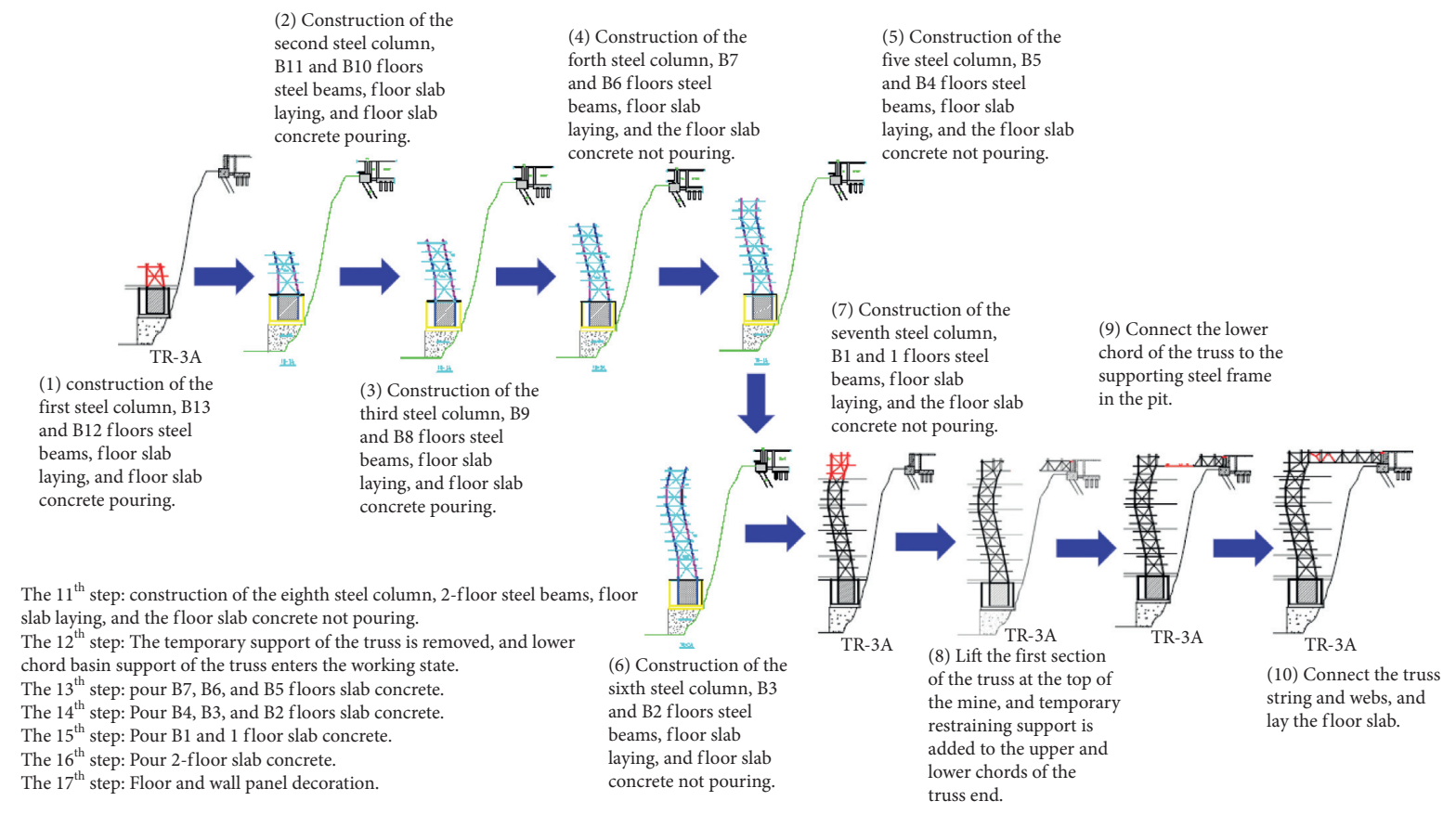

FIgURE 24: Schematic diagram of construction steps. 


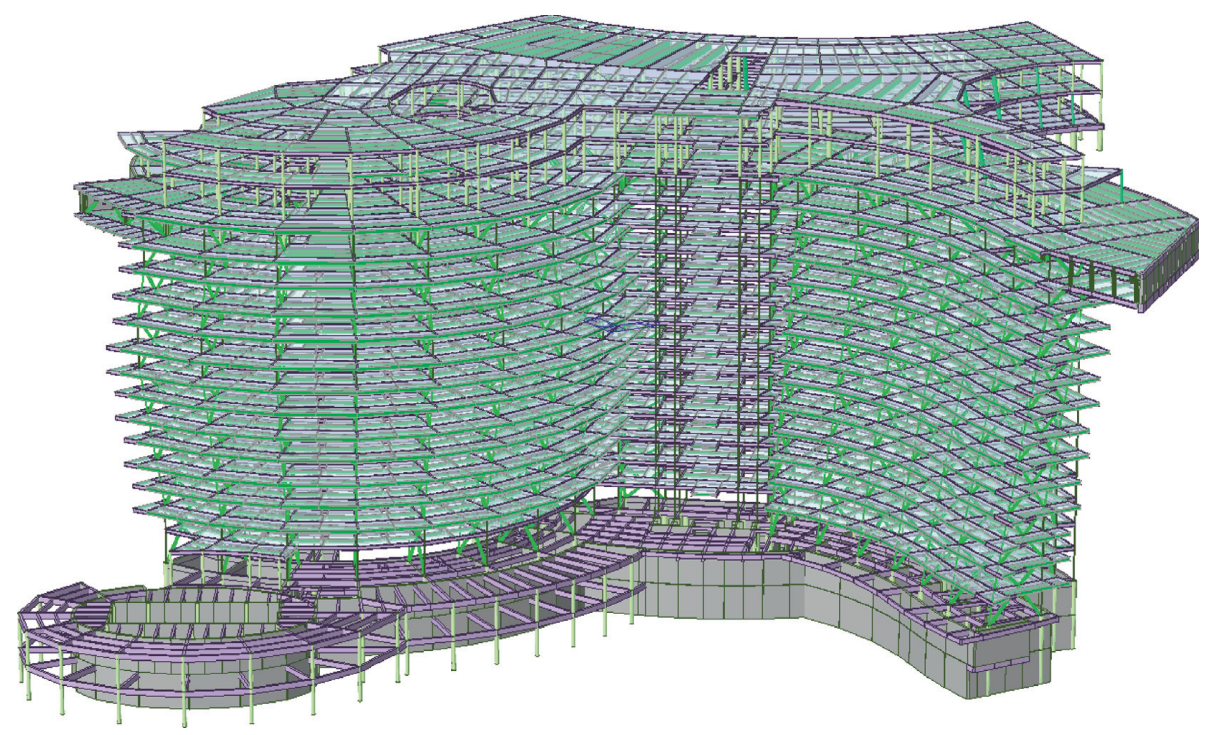

FIgUre 25: The FEA model of the building.

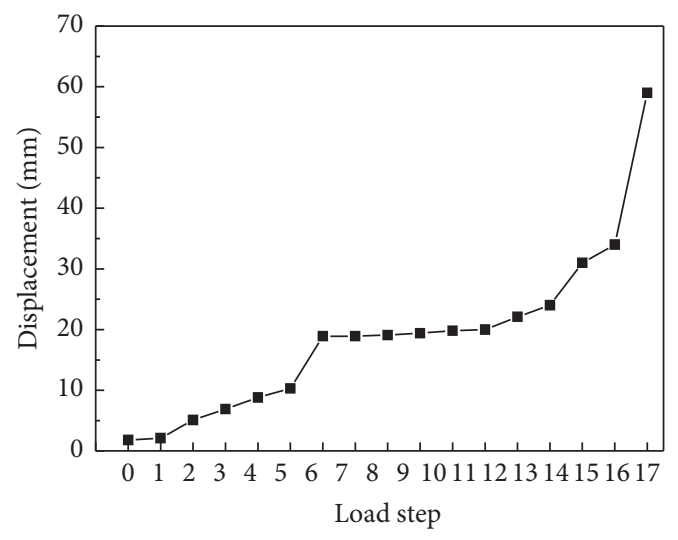

FIgURE 26: Calculated results of the displacement.

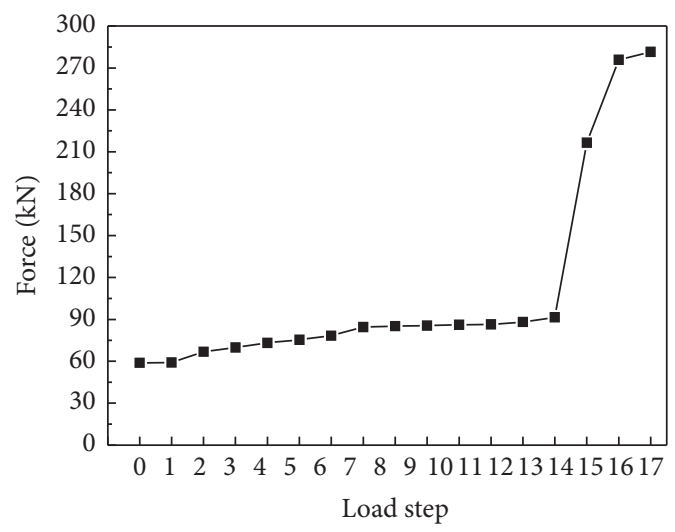

FIgURE 27: Calculated results of force.

The construction simulation calculation results showed that the internal forces and displacements of the members gradually increased from the $1^{\text {st }}$ load step to the $7^{\text {th }}$ load step, which was the stage of vertical truss formation. Since the floor slab concrete was not poured, the change of internal force and displacement of the members was small from the $8^{\text {th }}$ load step to the $11^{\text {th }}$ load step. This was the stage of spanning truss formation on the top of the pit. As the concrete load of the B7 to B2 floor slab was small, the corresponding changes in internal force and displacement were small from the $12^{\text {th }}$ load step to the $14^{\text {th }}$ load step. Due to the large load at this stage, the internal force and displacement changed significantly from the $15^{\text {th }}$ load step to the $17^{\text {th }}$ load step. The maximum deflection of the truss at the top of mine was $67 \mathrm{~mm}$, and the maximum deflection span ratio was $1 / 435$, which met the specification requirements of no more than $1 / 400$.

\section{Conclusion}

The Intercontinental Shanghai Wonderland is the world's first natural ecological hotel built in an abandoned mine. The most profound depth of the pit is $88 \mathrm{~m}$, and the slope foot of the deep pit cliff is about $80^{\circ}$. The cliff surface has been wholly weathered after years of weathering, which increased the difficulty of construction. According to the characteristics of this project, the conclusions can be drawn as follows:

(1) To ensure the stability of the slope of the main building during construction and operation, the geological structure of the mine pit was investigated and analyzed. The investigation results showed that there were nearly east-west compressive and torsional microfaults on the south side of the mine pit, with a dip angle of $195^{\circ}$. They are composed of mylonite and mylonitized broken rock where chloritization and clayization are common

(2) According to the geological conditions of the deep pit, the slope was supported by prestressed anchor cables, anchor bolt, and sprayed concrete. The dynamic response characteristics and the instability characteristics of the mine slope under the dynamic response were analyzed by the $3 \mathrm{D}$ dynamic finite element method. Under the conditions of anchoring support, the stability coefficients of the slope under 
static overload, small earthquake, and large earthquake were 2.0, 1.6, and 1.4, respectively. The calculation results showed that with effective anchoring support measures, the stability coefficient of slope under static load and small earthquakes was large, which had a certain safety margin. Under the action of large earthquakes, the slope could still meet the stability requirements

(3) A new type of two-point support structure was adopted according to the construction environment. The modal analysis of the Intercontinental Shanghai Wonderland was conducted through the finite element software ETABS and MIDAS. The calculated period ratios of the first mode and third mode of the outer part, Tower 1 , and Tower 2 were $0.86,0.62$, and 0.51 , respectively, which met the specification requirements

(4) The earthquake action of this project is very different from the ordinary building structure. The time history analysis method was used to solve the seismic design problem of this multipoint support structure. Three sets of seismic waves were calculated for a total of six working conditions. In the $X$ direction, the average values of the maximum base shear forces of Tower 1 and Tower 2 are $28011 \mathrm{kN}$ and $46007 \mathrm{kN}$, respectively. In the $Y$ direction, the average values of the maximum base shear forces of Tower 1 and Tower 2 are $38192 \mathrm{kN}$ and $14807 \mathrm{kN}$, respectively. Under each working condition, the maximum layer displacement angle was within $1 / 250$, which satisfied the limit requirement of $1 / 50$ of the seismic code. Some concrete-filled steel tubular columns produced plastic hinge at the bottom of the structure, and some steel supports produced plastic hinge at the top of the structure. The current structural system along with the design of component size and strength can meet the seismic performance of the structure under actions of rare earthquakes

(5) A set of ultradeep concrete downward conveying equipment, which was composed of three parts including a buffer hopper, a buffer device, and a buffer discharge port, was invented to solve the problem of $54431 \mathrm{~m} 3$ concrete transportation. The construction process of the structure was simulated by finite element software MIDAS. The maximum deflection of truss at the top of the mine was $67 \mathrm{~mm}$, and the maximum deflection span ratio was $1 / 435$, which met specification requirements of no more than $1 / 400$

\section{Data Availability}

The datasets generated during the current study are available in this paper and available also from the corresponding author on reasonable request.

\section{Conflicts of Interest}

The authors declare that there are no conflicts of interest regarding the publication of this paper.

\section{Acknowledgments}

The research reported herein was supported by a Research Grant no. 16DZ2250600 with funds given by the Shanghai Committee of Science and Technology.

\section{References}

[1] V. Meshchersky, "Dynamics of a particle of variable mass," PhD thesis, St Petersburg, Russia, 1897.

[2] R. V. Southwell, An Introduction to the Theory of Elasticity for Engineers and Physicists, Oxford University Press, New York, NY, USA, 1941.

[3] V. E. Naumov, "Mechanics of growing deformable solids: a review," Journal of Engineering Mechanics, vol. 120, no. 2, pp. 207-220, 1994.

[4] Z. Y. Cao, "Construction mechanics and time-varying mechanics in civil engineering," China Civil Engineering Journal, vol. 34, no. 3, pp. 41-46, 2001.

[5] H. Li, F. Zhou, J. Teng et al., "An analysis of monitored and computed strain of the National Aquatics Center in the states of unloading and daily use," China Civil Engineering Journal, vol. 45, no. 3, pp. pp1-9, 2008.

[6] F. Fan, H. Wang, X. Zhi et al., "Analysis of vertical deformation during construction of the Shanghai world financial center," Journal of Building Structures, vol. 31, no. 7, pp. 118-124, 2010.

[7] L. Tian, H. A. O. Jiping, T. Chen et al., "Simulation analysis on erection procedure of main stadium for the Universiade Sports Centre," Journal of Building Structures, vol. 32, no. 5, pp. 70-77, 2011.

[8] F. S. Lu, Q. Q. Wang, G. J. Zhou et al., "Key technology for large-scale grid structure construction of the roof of corridor in Chongqing Jiangbei international airport," Steel Constuction, vol. 30, no. 198, pp. 81-85, 2015.

[9] Q. Yang, S. Yu, X. Zhang, Z. Wang, J. Yan, and X. Chen, “The construction technology of roof steel structure in YanCheng NanYang airport," Advances in Civil Engineering, vol. 2018, Article ID 6386020, 12 pages, 2018.

[10] W. Zhang, S. Yu, X. Zhang, J. Yan, and X. Chen, "Construction process simulation and in situ monitoring of dendritic structure on nanjing Niushou mountain," Shock and Vibration, vol. 2019, Article ID 1873479, 13 pages, 2019.

[11] L. Yan, R. Li, and Z. Li, "Research on construction unloading monitoring technology of $120 \mathrm{~m}$ triangular pyramidal space steel structure," Journal of Building Structures, vol. 41, no. 2, pp. 142-148, 2020.

[12] T. Li, D. Li, C. Xu et al., "Vertical deformation of super highrise steel reinforced concrete frame-core hybrid structures," Journal of Building Structures, vol. 41, no. 2, pp. 142-148, 2020.

[13] S. Zhong, Unified Theory of Concrete-filled Steel Tube: Research and Application, Tsinghua University Press, Beijing, China, 2006. 